\title{
Analysis on factors affecting nausea and vomiting severity suffered by patients in the early phase of hemodialysis therapy
}

\author{
Muhammad Rafi Fathurrohman ${ }^{1}$, Sri Suparti ${ }^{2}$ \\ ${ }^{1,2}$ Medical Surgical of Nursing Department, Universitas Muhammadiyah Purwokerto, Indonesia
}

\begin{tabular}{l} 
ARTICLE INFO \\
\hline Article history: \\
Received: August 9, 2020 \\
Revised: August 20, 2020 \\
Accepted: August 30, 2020 \\
\hline
\end{tabular}

\section{Keywords:}

severity, nausea, vomiting, factor

\begin{abstract}
Nausea and vomiting should be further checked and prevented, because these conditions can be a cause or complication during hemodialysis patients. Electrolyte and water imbalance (dehydration) can be considered as the main complication of nausea and vomiting itself. The aim of this study was to determine the factors that influence the severity of nausea and vomiting in patients undergoing hemodialysis. This type of research is quantitative with analytic descriptive method, with an approach using a retrospective cohort research design. The sampling technique in this study was a total sampling technique with a total sample of 57 patients. The research instrument used questionnaires and observations, data analysis using the Chi Square test and simple logistic regression analysis. The location of the study was the hemodialysis therapy site at the Islamic Hospital in Purwokerto in JanuaryFebruary 2020. The results showed that most of the respondents with the severity of nausea and vomiting, the patient's diet was not balanced $(61.4 \%)$, the excess fluid had edema $(63.2 \%)$, the gender was male $(59.6 \%)$, female (40.4\%). \%), age 18-65 (57.9\%), duration of HD $<12$ months $(64.9 \%)$ and 58 respondents> 12 months (35.1). The results of bivariate analysis using logistic regression, obtained $\mathrm{p}$ value of the patient's diet 0.009 , excess fluid, age and sex 0.001 and the duration of HD 0.003. From this analysis, there are 5 factors that can cause the severity of nausea and vomiting, namely the patient's diet, excess fluidity, gender, age, and duration of HD.
\end{abstract}

This work is licensed under a Creative Commons Attribution 4.0 International License.

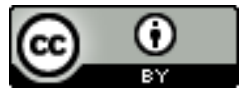

\section{Corresponding Author:}

Muhammad Rafi Fathurrohman

Department of Health, Universitas Muhammadiyah Purwokerto

Soepardjo Rustam Street KM. 7, Banyumas, Indonesia

Email: rafifathurrohman30@gmail.com

\section{INTRODUCTION}

Nausea and vomiting are one of the most common complications in the early phase during hemodialysis, in a study [1] of the incidence of gastrointestinal symptoms in regular hemodialysis patients in the form of anorexia, nausea, vomiting and initial feelings of fullness when eating. The reported incidence of nausea and vomiting was $18.2 \%$ and $9.8 \%$, respectively [1], 25,8\% [2]. Another study stated that the incidence of nausea and vomiting during hemodialysis was $28.3 \%$ and $11.7 \%$, respectively. Meanwhile, the severity of nausea was 1.15 and the mean vomiting rate was 2.08. Nausea and vomiting occur for various reasons after the start of hemodialysis. Many patients experience these symptoms during hemodialysis because of a rapid drop in blood pressure or urea [2]. According to [3] in the incidence of nausea and vomiting in Indonesia during hemodialysis was 5\%, in 2016 according to the IRR it was 5.5\%, in 2017 it was 6\%. Body weight and interdialytic weight gain (IDWG) can also cause nausea and vomiting in hemodialysis patients [4]. Hypotension, anxiety, body position during hemodialysis, gender and age, patient diet, treatment regimen, excess fluid, body weight, interdialytic weight gain (IDWG). Excess fluid is also associated with mucosal edema in the digestive system, discomfort, nausea, vomiting, and diarrhea [1]. Nausea and vomiting are early signs of disequilibrium dialysis syndrome, hyperkalemia, inadequate dialysis, and the presence of excessive urea levels [5]. 
Nausea and vomiting must be further and prevented, because these conditions can become complications or complications during hemodialysis patients. Electrolyte and water imbalance (dehydration) can be a major complication of nausea and vomiting itself. Electrolyte and water imbalance after vomiting. The goal of hemodialysis is to maintain proper and safe serum electrolyte concentration [2]. Nausea when not treated promptly can vomit, resulting in stomach irritation. Chronic nausea and vomiting can lead to hematemesis and melena, leading to anemia; if such conditions persist for a long time, the patient will experience decreased quality of life and even death [6]. Nausea and vomiting of patients undergoing hemodialysis will cause complications such as fluid and electrolyte balance disorders that interfere with patient safety and increase health costs [1]. Based on a preliminary study, of the $50 \%$ of patients who were on therapy on Tuesday, October 22, 2019, hemodialysis on that day mostly had nausea and vomiting during intra and post hemodialysis and only $5 \%$ to $6 \%$ of people experienced nausea and vomiting before hemodialysis. . Hemodialysis is a very important action and is a replacement therapy, various complications pre, intra and post often occur in hemodialysis patients, especially during hemodialysis within 1-4 hours and one of them is nausea and vomiting. The novelty of this study is to examine the severity of nausea and vomiting during hemodialysis.

\section{RESEARCH METHOD}

The study is quantitative with a descriptive analytic method and a restospestive cohort approach. The population were pations who underwent hemodialtsis therapy at the Islamic Hospital Purwokerto with a total of 57 patients. The totl sampling technique is used. The research was conducted in January to February 2020. Questionnaries and observational sheets were used to obtain information from respondents. Chi Square test and simple logistic regression analysis were used to analyse the data.

\section{RESULTS AND DISCUSSIONS}

Table 1. Respondent Characteristics $(\mathrm{n}=57)$

\begin{tabular}{lcc}
\hline Variable & Frequency & Percentage \\
\hline Severity Of Nausea and Vomiting & 38 & \\
$\quad$ Severe & 19 & $66,7 \%$ \\
$\quad$ Not Severe & & $33,3 \%$ \\
Age & 33 & \\
$\quad$ Influence (18-65) & 24 & $57,9 \%$ \\
$\quad$ Not Influence (>65) & & $42,1 \%$ \\
Gender & 34 & $59,6 \%$ \\
$\quad$ Male & 23 & $40,4 \%$ \\
$\quad$ Female & & \\
The Patients Diet & 23 & $38,6 \%$ \\
$\quad$ Balanced & 34 & $61,4 \%$ \\
$\quad$ Not Balanced & & \\
Excess Fluid & 36 & $63,2 \%$ \\
$\quad$ Edema & 21 & $36,2 \%$ \\
$\quad$ No Edema & & \\
Duration HD & 37 & $64,9 \%$ \\
$\quad<12$ month & 20 & $35,1 \%$ \\
$\quad>12$ month & 57 & $100 \%$ \\
\hline Total &
\end{tabular}

The results showed that most of the respondents with a history of severe nausea and vomiting with an unbalanced patient's diet (61.4\%), edema (63.2\%), male (59.6\%) female (40.4\%) ), ages 18-65 (57.9\%), duration of $\mathrm{HD}<12$ months $(64 \%)$ and $>12$ months (35.1). To determine the relationship between variables and the incidence of nausea and vomiting, chi square analysis and simple logistic regression was used.

Tabel 2. Relationship between factors and severity of nausea and vomiting $(n=57)$

\begin{tabular}{lccccc}
\hline \multicolumn{1}{c}{ Variabel } & \multicolumn{2}{c}{ Nausea Vomiting } & p-value & OR & IK 95\% \\
\hline Diet & No Severe & & & \\
$\quad$ Balanced & $10(26,3 \%)$ & $12(63,2 \%)$ & 0,009 & 4,8 & $1,4-15,6$ \\
$\quad$ Not Balanced & $28(73,7 \%)$ & $7(36,8 \%)$ & & & \\
Fluid & & & & & \\
$\quad$ Edema & $32(84,2 \%)$ & $4(21,1 \%)$ & 0,001 & 0,050 & $0,012-0,204$ \\
$\quad$ No Edema & $6(15,8 \%)$ & $15(78,9 \%)$ & & &
\end{tabular}




\begin{tabular}{llllll} 
Gender & & & & \\
$\quad$ Male & $31(81,6 \%)$ & $3(15,8 \%)$ & 0,001 & 0,42 & $0,010-0,186$ \\
$\quad$ Female & $7(18,4 \%)$ & $16(84,2 \%)$ & & & \\
$\begin{array}{l}\text { Age } \\
(18-65)\end{array}$ & $30(78,9 \%)$ & $3(15,8 \%)$ & 0,001 & 0,050 & $0,012-0,215$ \\
$\quad(>65)$ & $8(21,1 \%)$ & $16(84,2 \%)$ & & & \\
$\begin{array}{c}\text { Duration HD } \\
\quad<12 \text { month }\end{array}$ & $30(78,9 \%)$ & $7(36,8 \%)$ & 0,003 & 0,156 & $0,046-0,524$ \\
$>12$ month & $8(21,1 \%)$ & $12(63,2 \%)$ & & & \\
\hline
\end{tabular}

Of all patients aged 18-65 years 78.9\% had very severe nausea and vomiting, whereas of all patients aged $>65$ years only $21.1 \%$ had severe nausea and vomiting. These results differ from research conducted by Asgari in 2017, which found that the majority of subjects in his study were $(51.7 \%)$ included in the age group 60 years and over and only a minority (8.3\%) were below the age range. 20 to 39, the mean age of the subjects was 59.5 years. At a young age, kidney failure can occur due to chronic dehydration or nephrotoxic substances. Consumption of food or drinks containing nephrotoxic substances will accelerate the destruction of kidney cells. In old adulthood and the elderly, anatomically the ability to grow kidney cells begins to decline and the function of kidney cells begins to decline [7].

In a study by [8] the mean age of hemodialysis patients examined was 55.5 years. Correspondingly in a study by [9] most of the patients were over 60 years of age and included in the 45-64 age group who experienced severe nausea and vomiting. Moreover in a study by [10] the mean age of those with nausea and vomiting was 54.8 and their age range was 20 to 80 . For the sex factor of all male patients, $81.6 \%$ had very severe nausea and vomiting, while only $18.4 \%$ of all female patients had severe nausea and vomiting. The results of this study are in accordance with the research conducted by Asgari that men experience more nausea and vomiting than women. As many as $56.7 \%$ of the subjects examined in his study [2] were male and $43.3 \%$ female. In a study conducted by Ghahri Sarabi on dialysis complications and associated factors in hemodialysis patients, out of a total of 192 subjects, $59.9 \%$ were male and $40.1 \%$ were female.

Several other studies have also reported more male patients than women $[11,12,8,13]$. This is possible because the male urinary tract is longer, allowing a high barrier to excrete urine from the bladder. According to Ganong in [7] men are at risk of developing CRF compared to women. This is because women have more estrogen. The hormone estrogen can affect calcium levels in the body by inhibiting the formation of certain cytokines to prevent osteoclasts from absorbing excessively into bone. From the results of the study, it can be concluded that gender is a factor that affects the severity of nausea and vomiting in patients undergoing hemodialysis. Of all the patients whose diets were not balanced $73.7 \%$ had very severe nausea and vomiting, whereas of all patients whose diets were balanced only $26.3 \%$ had severe nausea and vomiting. In this study, it was found that most of the respondents had an unbalanced diet of patients with nausea and vomiting. The development of a renal diet plan includes restrictions on fluid, sodium, potassium, and phosphate intake and may include iron, vitamin, and calcium supplementation. On a calorie basis, critically ill patients with renal failure need a calorie diet totaling 30 to $44 \mathrm{kcal} / \mathrm{kg} /$ day, most of which should consist of a combination of carbohydrates and lipids. In addition, amino acids, both essential and nonessential, should be administered to minimize catabolism [14].

Research conducted by [15] states that foods that can be consumed include eggs, meat, fish and chicken, and that offal (liver, intestines, spleen) are foods that need to be avoided, as well as tempeh and tofu should be limited, then to consume The fruit is cut into pieces and then washed and soaked in warm water. Adequate food intake in hemodialysis patients is an important pillar in supporting the nutritional status and quality of life of patients with chronic kidney disease (CKD) in undergoing hemodialysis. Adequate energy supply is essential to make nitrogen balance positive. In addition, adequate intake of macro and micro nutrients and according to recommendations can also improve the balance and intake of food into the stomach [16]. From this study it can be concluded that the patient's diet is a factor affecting the severity of nausea and vomiting in patients undergoing hemodialysis.

Vitamin B6 deficiency, especially in its role in amino acid utilization and fat metabolism, has a major role as a coenzyme. In addition, folic acid, vitamin B6 and or vitamin B12 can affect the normal functioning of the body [17]. From this study it can be concluded that the patient's diet is a factor that affects the severity of nausea and vomiting in patients undergoing hemodialysis. In hemodialysis patients there is a risk of losing vitamin B1 (thiamin), especially when accompanied by low protein and potassium intake. Micro mineral intake such as iron, potassium, and sodium is also a concern in hemodialysis patients. Anemia cases are also often found in dialysis patients. This is because the amount of iron absorbed in the small intestine is reduced and the formation of erythropoietin is reduced due to the suppression of the spinal cord by urea. Potassium and sodium restriction is also required in dialysis patients, especially those with anuria [18]. 
The results showed that $84.2 \%$ of patients with edema (excess fluid) experienced very severe nausea and vomiting, while of all patients without edema, only $15.8 \%$ had severe nausea and vomiting. The need for fluids in chronic renal failure disease must be adjusted to a predetermined fluid intake limit, the thirst experienced by the patient causes the phenomenon of fluid overload in clients undergoing hemodialysis therapy. Daily body weight is an important parameter monitored, in addition to an accurate record of intake and output [15]. Excess fluid in CKD patients is associated with several incidences of mucosal edema in the digestive system [1]. Changes that occur in the body due to clinical manifestations of CKD itself, as well as access to blood circulation during hemodialysis, will increase anxiety [19]. Increased anxiety will stimulate the midbrain and CTZ as a central route from the vomiting center [20].

According to researchers, the factor that causes edema is excess fluid because during hemodialysis therapy the fluid circulation is not controlled which can accumulate fluid. causing edema in the patient's feet and hands resulting in nausea and vomiting in patients undergoing hemodialysis therapy. The buildup of fluids in the body causes heavy heart and lung function, which results in the patient getting tired, shortness of breath and nausea as well as vomiting. In hemodialysis patients it is recommended to limit or reduce the consumption of fluids in a day. Hemodialysis patients pass urine no more than 200-300 mL per day. Therefore, patients are advised to consume fluids of no more than $500 \mathrm{~mL}$ or the equivalent of 2 glasses per day. This recommendation is accompanied by recommendations for limiting salt consumption. Excess water and salt consumption will cause pulmonary edema, a condition where fluid enters the lungs, hypertension, shortness of breath, chills, anxiety, panic, muscle spasms and causes severe nausea and vomiting in patients undergoing hemodialysis therapy [21].

Duration of hemodialysis was related to the severity of nausea and vomiting, all patients who underwent hemodialysis < 12 months $78.9 \%$ had very severe nausea and vomiting, whereas of all patients who underwent> 12 months only $21.1 \%$ had severe nausea and vomiting. The mean hemodialysis patient was 46.32 months, this duration exceeding 48 months (26.7\%). In study [8] 70\% of patients had a history of hemodialysis for 40-60 months. Moreover, in a study by [11] the mean duration of hemodialysis was 31.75 months. However, in study [10], most of the subjects had hemodialysis duration of less than 2 years with a mean of 4.8 years. In contrast to study [22], patients with a long duration of hemodialysis (> 36 months) were at risk for arterial stiffness. This condition can worsen the severity of nausea and vomiting based on the theory of overactivity of the sympathetic system, including the occurrence of vasocontraction. The life expectancy of patients with CRF increases with improved dialysis techniques. However, dialysis does not fully restore the patient's quality of life to normal. Although periodic dialysis prevents death from uremia, the patient's low life expectancy remains a problem. When renal replacement therapy has been started, the patient life expectancy is about 8 years for dialysis patients aged 40-44 years, and about 4.5 years for patients aged 60-64 years [23].

\section{CONCLUSION}

From this analysis, there are 5 factors that can cause the severity of nausea and vomiting, namely the patient's diet, excess fluid, gender, age, and duration of HD. For ages 18-65 years 78.9\% experienced severe nausea and vomiting. For the dominant male gender, $81.6 \%$ experienced the severity of nausea and vomiting. For the patient's diet that was not balanced $73.3 \%$ experienced severe nausea and vomiting. For the excess fluid there was edema, $84.2 \%$ experienced the severity of nausea and vomiting. And for the factor of duration of HD $<12$ months $78.9 \%$ experienced the severity of nausea and vomiting.

\section{Acknowledgments}

Thank you for the support to the Chancellor of the Islamic Hospital of Purwokerto who gave permission to researchers so that they could carry out research in the hemodialysis therapy room. Thank you to the health workers in the hemodialysis room of the Islamic Hospital of Purwokerto who have helped in the data collection process in this study.

\section{REFERENCES}

[1] V. U. I. H. Chong and J. Tan, "Prevalence of gastrointestinal and psychosomatic symptoms among Asian patients undergoing regular hemodialysis Correspondence : ABSTRACT : Aim : Gastrointestinal ( GI ) symptoms are reported to be common among," vol. 18, pp. 97-103, 2013, doi: 10.1111/nep.12000.

[2] M. R. Asgari, F. Asghari, A. A. Ghods, R. Ghorbani, N. H. Motlagh, and F. Rahaei, "Incidence and severity of nausea and vomiting in a group of maintenance hemodialysis patients," J. Ren. Inj. Prev., vol. 6, no. 1, pp. 49-55, 2017, doi: 10.15171/jrip.2017.09.

[3] P. Indonesian et al., "9 th Report Of Indonesian Renal Registry 2016,” pp. 1-46, 2017.

[4] S. Suparti and H. Febrianti, "Intradialytic complication and IDWG " vol. 11, no. December, 2019.

[5] S. R. Borzou, F. Mahdipour, K. Oshvandi, M. Salavati, and N. Alimohammadi, "Effect of Mealtime During Hemodialysis on Patients' Complications," J. Caring Sci., vol. 5, no. 4, pp. 277-286, 2016, doi: 
$10.15171 /$ jcs.2016.029.

[6] S. Alam \& I. Hadibroto., 2008.Gagal Ginjal. Jakarta: PT. Gramedia Pustaka Albano, V.A., 2001.," vol. 57, no. July, pp. 36-39, 2016.

[7] Ratnawati, "Kepatuhan Pembatasan Asupan Cairan Terhadap Lama Menjalani," pp. 104-112, 2014.

[8] M. T. E, N. M. S, S. Samiey, B. Einollahi, and B. G. R, "Effect of programmed nursing care in prevention of hemodialysis complications Effect of programmed nursing care in prevention of hemodialysis complications," no. January 2015, 2009.

[9] A. Monfared and M. Khosravi. 'Orang poor R, Moosavian Roshan Zamir SA, Aghajani Nargesi D.' Reasons of chronic renal failure in hemodialysis patients in Guilan province. J of Guilan univ of med sci 12.46 (2003): 76-83."

[10] A. R. Sarabi., et al. 'Assessment of Complications during Hemodialysis and its relative factors in patients under hemodialysis in selected hospitals in Hamadan province.' J Nurs Midwifery Coll Shahid Beheshti Univ Med Sci 21 (2011): 37-44."

[11] M. R. Asgari, F. Asghari, A. A. Ghods, R. Ghorbani, and N. Hoshmand, "The Effect of Acupressure on the Severity of Nausea During Hemodialysis," vol. 7, no. 1, pp. 77-81, 2020.

[12] C. Zou et al., "Auricular acupressure on specific points for hemodialysis patients with insomnia:A pilot randomized controlled trial," PLoS One, vol. 10, no. 4, pp. 1-13, 2015, doi: 10.1371/journal.pone.0122724.

[13] A. Shariati, S. Jahani, M. Hooshmand, and N. Khalili, "The effect of acupressure on sleep quality in hemodialysis patients," Complement. Ther. Med., vol. 20, no. 6, pp. 417-423, 2012, doi: 10.1016/j.ctim.2012.08.001.

[14] M. P. Gonce, Keperawatan Kritis. 2012.

[15] K. Hikmawati, "Pengetahuan Pasien Tentang Diet Cairan dan Nutrisi pada Pasien Gagal Ginjal Kronik ( GGK ) Di Ruang Hemodialisa RSUD Kabupaten Indramayu Tahun 2017,” vol. 7, 2019.

[16] A. T. Astuti and S. Septriana, "Asupan energi, zat gizi makro, dan zat gizi mikro pada pasien hemodialisis di RSUD Panembahan Senopati Bantul," J. Nutr., vol. 20, no. 2, pp. 45-52, 2018, doi: 10.29238/jnutri.v20i2.36.

[17] A. S. Wierzbicki, "Homocysteine and cardiovascular disease : a review of the evidence," vol. 4, no. 2 , pp. 143-149, 2007, doi: 10.3132/dvdr.2007.033.

[18] F. E. Güneş, "Medical Nutrition Therapy for Hemodialysis Patients," 2012.

[19] S. L. Lewis, S. R. Dirksen, M. M. Heitkemper, and L. Bucher, Medical-Surgical Nursing : Assessment and Management of Clinical Problems, 9th ed. Elsevier Inc.

[20] Ferrell, Betty R.; Coyle, Nessa; Paice, Judith (ed.). Oxford textbook of palliative nursing. Oxford University Press, 2014."

[21] K. Denhaerynck., D. Manhaeve., F. Dobbels., D. Garzoni., C. Nolte., \& S. De Geest., (2007). Prevalence and consequences of nonadherence to hemodialysis regimens. American Journal of Critical Care, 16(3), 222-235."

[22] T. Nakashima et al., "Evidence for osteocyte regulation of bone homeostasis through RANKL expression," Nat. Med., vol. 17, no. 10, pp. 1231-1234, 2011, doi: 10.1038/nm.2452.

[23] W. Suryaningsih.M, Kanine E, "Cross Sectionalstudy," Hub. Dukungan Kel. Dengan Depresi Pada Pasien Penyakit Ginjal Kron. Di Ruangan Hemodialisa BLURSUP Prof. Dr. RD. KANDOU Manad., vol. 1, 2013, [Online]. Available: download.portalgaruda.org/article.php?article=141034\&val=5798. 